\title{
Regulation of New Depleted Uranium Uses
}

Environmental Assessment Division Argonne National Laboratory

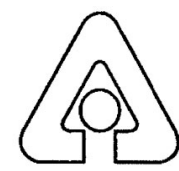

Operated by The University of Chicago, under Contract W-31-109-Eng-38, for the

United States Department of Energy 
Argonne National Laboratory, with facilities in the states of Illinois and Idaho, is owned by the United States Government and operated by The University of Chicago under the provisions of a contract with the U.S. Department of Energy.

\section{DISCLAIMER}

This report was prepared as an account of work sponsored by an agency of the United States Government. Neither the United States Government nor any agency thereof, nor The University of Chicago, nor any of their employees or officers, makes any warranty, express or implied, or assumes any legal liability or responsibility for the accuracy, completeness, or usefulness of any information, apparatus, product, or process disclosed, or represents that its use would not infringe privately owned rights. Reference herein to any specific commercial product, process, or service by trade name, trademark, manufacturer, or otherwise does not necessarily constitute or imply its endorsement, recommendation, or favoring by the United States Government or any agency thereof. The views and opinions of document authors expressed herein do not necessarily state or reflect those of the United States Government or any agency thereof, Argonne National Laboratory, or The University of Chicago.

Available electronically at http://www.doe.gov/bridge

Available for a processing fee to U.S. Department of Energy and its contractors, in paper, from:

U.S. Department of Energy

Office of Scientific and Technical Information

P.O. Box 62

Oak Ridge, TN 37831-0062

phone: (865) 576-8401

fax: (865) 576-5728

mail: reports@adonis.osti.gov 
ANL/EAD/TM/02-5

\section{Regulation of New Depleted Uranium Uses}

by Nancy L. Ranek

Environmental Assessment Division

Argonne National Laboratory, 9700 South Cass Avenue

Argonne, Illinois 60439

December 2002

Work sponsored by Oak Ridge National Laboratory under contract to the U.S. Department of Energy, Office of the Deputy Assistant

Secretary of Site Closure, Oak Ridge Office, Oak Ridge, Tennessee 


\section{NOTICE}

This technical memorandum is an information product of Argonne's Environmental Assessment Division

(EAD). It presents results of ongoing work or work that is more limited in scope and depth than that described in formal reports issued by EAD. This memorandum has undergone internal technical review and has been edited according to EAD's quality assurance requirements. In contrast to a formal technical report, this memorandum has not been externally peer reviewed.

For more information on the division's scientific and engineering activities, contact:

Director, Environmental Assessment Division

Argonne National Laboratory

Argonne, Illinois 60439

Telephone (630) 252-3107

email: ead@anl.gov

Publishing support services were provided by Argonne's Information and Publishing Division (for more information, see IPD's home page:

http://www.ipd.anl.gov). 


\section{CONTENTS}

NOTATION $\ldots \ldots \ldots \ldots \ldots \ldots \ldots \ldots \ldots \ldots \ldots \ldots \ldots \ldots \ldots \ldots \ldots$

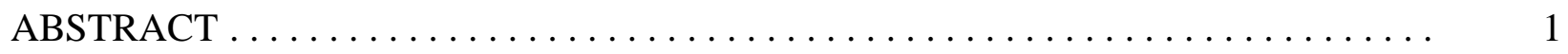

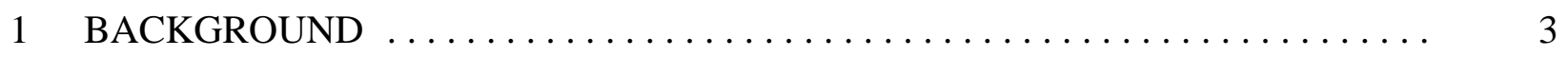

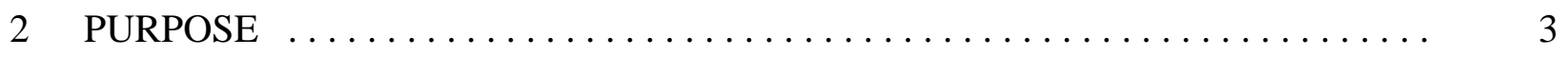

3 EXISTING REGULATORY STRUCTURE $\ldots \ldots \ldots \ldots \ldots \ldots \ldots \ldots \ldots$

3.1 Transfer of DU from a DOE-Controlled Conversion Facility to a Non-DOE Manufacturing Facility $\ldots \ldots \ldots \ldots \ldots \ldots \ldots \ldots \ldots$

3.2 Manufacture of Industrial Products and Devices Containing DU and Transfers of These Products and Devices to Users . . . . . . . . . . . . 5

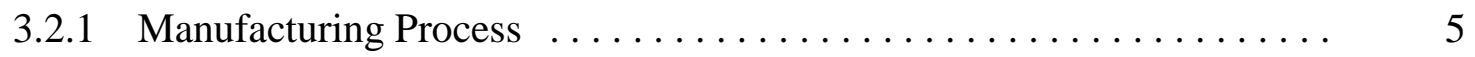

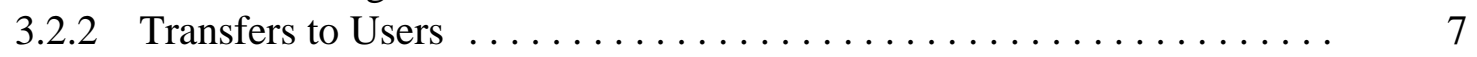

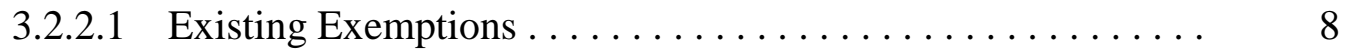

3.2.2.2 Existing General Licenses .................... 9

3.3 New Uses of DU in Radiologically Uncontrolled Areas . . . . . . . . . . . . . . . . . . 10

3.3.1 Catalysts That Destroy Volatile Organic Compounds . . . . . . . . . . . . . 10

3.3.2 Catalysts Used for Hydrodesulfurization of Petroleum Fuels . . . . . . . . 11

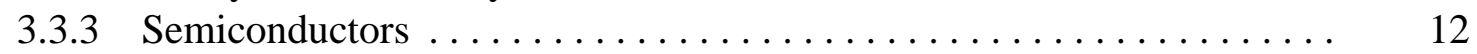

3.3.4 Electrodes Used in Fuel Cells . . . . . . . . . . . . . . . . . . . . 13

3.3.5 Electrodes Used in the Production of Hydrogen . . . . . . . . . . . . . . . 14

3.3.6 Electrodes Used in Batteries . . . . . . . . . . . . . . . . . . . . 15

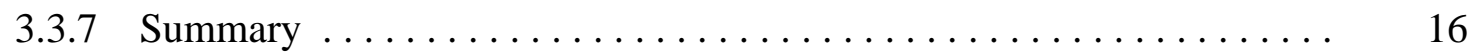

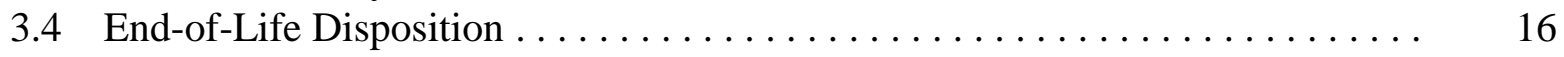

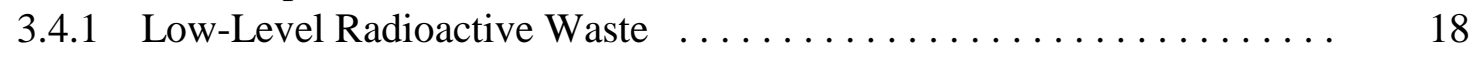

3.4 .2 Low-Level Mixed Waste . . . . . . . . . . . . . . . . . . . . . 19

4 ONGOING FEDERAL REGULATORY DEVELOPMENT ACTIVITIES

THAT MAY CHANGE THE EXISTING REGULATORY STRUCTURE . . . . . . 19

4.1 Introduction $\ldots \ldots \ldots \ldots \ldots \ldots \ldots \ldots \ldots \ldots \ldots \ldots \ldots \ldots \ldots \ldots . \ldots \ldots \ldots$

4.2 Interagency Jurisdictional Working Group for Evaluating the Regulation of Source Materials Containing Less than 0.05 Percent by Weight

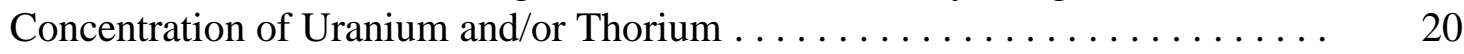

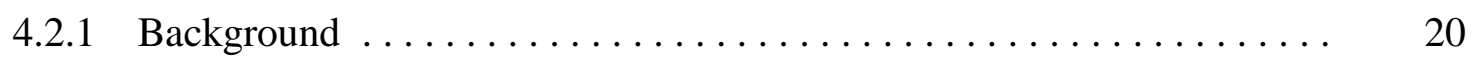

4.2.2 Possible Regulatory Changes and Potential Effects on

Existing Regulatory Structure Applicable to New DU Uses . . . . . . . . 21

4.3 Rulemaking: Distribution of Source Material to Exempt Persons and to General Licensees and Revision of 10 CFR 40.22 General License . . . . . . 23

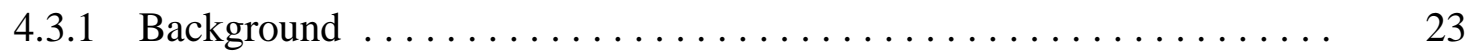




\section{CONTENTS (Cont.)}

\subsubsection{Possible Regulatory Changes and Potential Effects on}

Existing Regulatory Structure Applicable to New DU Uses . . . . . . . . 23

4.3.2.1 Changes to 10 CFR 40.22 .................. 23

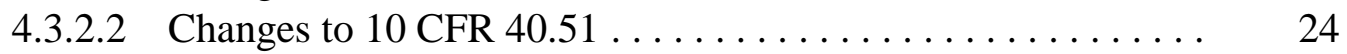

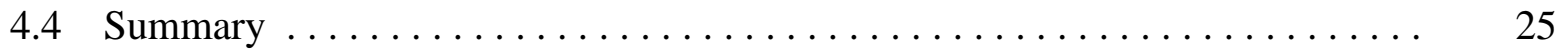

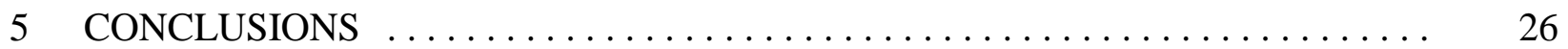

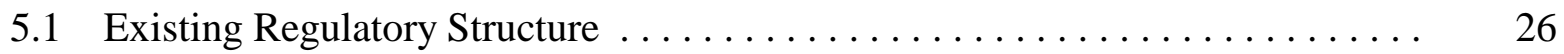

5.2 Modified Regulatory Structure $\ldots \ldots \ldots \ldots \ldots \ldots \ldots \ldots \ldots \ldots \ldots \ldots \ldots \ldots \ldots$

6 RECOMMENDATIONS $\ldots \ldots \ldots \ldots \ldots \ldots \ldots \ldots \ldots \ldots \ldots \ldots \ldots \ldots \ldots$

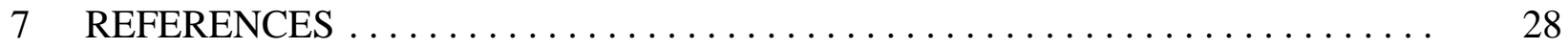

APPENDIX A: Specific License Application Content and Process Requirements . . . . 31

APPENDIX B: U.S. Nuclear Regulatory Commission Rulemaking Petition Content and Process Requirements and Guidance ........... 35

APPENDIX C: $\quad$ Glossary $\ldots \ldots \ldots \ldots \ldots \ldots \ldots \ldots \ldots \ldots \ldots \ldots \ldots \ldots \ldots \ldots \ldots$

\section{FIGURE}

1 Pathway from DUF $_{6}$ Conversion to End-of-Life Disposition

\section{TABLES}

1 Overview of Existing Regulatory Structure $\ldots \ldots \ldots \ldots \ldots \ldots \ldots \ldots \ldots \ldots$

2 Existing Exemptions from NRC and Agreement State Source Material

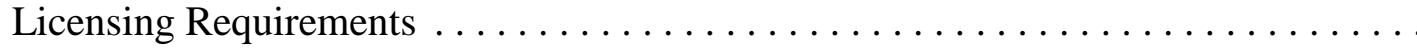

3 Existing General Licenses for Source Material $\ldots \ldots \ldots \ldots \ldots \ldots \ldots \ldots \ldots \ldots$

4 Availability of Existing NRC or Agreement State Exemptions and General Licenses to Users of New DU Products and Devices in Radiologically Uncontrolled Areas 


\section{NOTATION}

The following is a list of acronyms, initialisms, and abbreviations (including units of measure) used in this document.

\section{ACRONYMS, INITIALISMS, AND ABBREVIATIONS}

$\begin{array}{ll}\text { AEA } & \text { Atomic Energy Act of 1954 } \\ \text { CFR } & \text { Code of Federal Regulations } \\ \text { CRCPD } & \text { Conference of Radiation Control Program Directors } \\ \text { DOE } & \text { U.S. Department of Energy } \\ \text { DU } & \text { depleted uranium } \\ \text { DUF } & \text { depleted uranium hexafluoride } \\ \text { EPA } & \text { U.S. Environmental Protection Agency } \\ \text { FR } & \text { Federal Register } \\ \text { HDS } & \text { hydrodesulfurization } \\ \text { LLRWPAA } & \text { Low-Level Radioactive Waste Policy Amendments Act } \\ \text { LLW } & \text { low-level radioactive waste } \\ \text { NPRM } & \text { notice of proposed rulemaking } \\ \text { NRC } & \text { U.S. Nuclear Regulatory Commission } \\ \text { NWPA } & \text { Nuclear Waste Policy Act } \\ \text { OAS } & \text { Organization of Agreement States } \\ \text { OSHA } & \text { Occupational Safety and Health Administration } \\ \text { PEC } & \text { photoelectrochemical } \\ \text { R\&D } & \text { research and development } \\ \text { RCRA } & \text { Resource Conservation and Recovery Act } \\ \text { SOFC } & \text { solid oxide fuel cell } \\ \text { UO } & \text { uranium dioxide } \\ \text { U.S.C. } & \text { United States Code } \\ \text { VOC } & \text { volatile organic compound } \\ & \end{array}$

\section{UNITS OF MEASURE}

$\begin{array}{ll}\mathrm{ft} & \text { foot (feet) } \\ \mathrm{in} . & \text { inch(es) } \\ \mathrm{lb} & \text { pound(s) } \\ \mathrm{kg} & \text { kilogram(s) } \\ \mathrm{mg} & \text { milligram(s) } \\ \mathrm{mrem} & \text { millirem(s) } \\ \mathrm{mSv} & \text { millisievert(s) } \\ \mathrm{ppm} & \text { parts per million } \\ \mathrm{yr} & \text { year(s) }\end{array}$




\title{
REGULATION OF NEW \\ DEPLETED URANIUM USES
}

by

Nancy L. Ranek

\begin{abstract}
This report evaluates how the existing U.S. Nuclear Regulatory Commission (NRC) regulatory structure and pending modifications would affect full deployment into radiologically uncontrolled areas of certain new depleted uranium (DU) uses being studied as part of the U.S. Department of Energy's DU uses research and development program. Such new DU uses include as catalysts (for destroying volatile organic compounds in off-gases from industrial processes and for hydrodesulfurization [HDS] of petroleum fuels), semiconductors (for fabricating integrated circuits, solar cells, or thermoelectric devices, especially if such articles are expected to have service in hostile environments), and electrodes (for service in solid oxide fuel cells, in photoelectrochemical cells used to produce hydrogen, and in batteries). The report describes each new DU use and provides a detailed analysis of whether any existing NRC licensing exemption or general license would be available to users of products and devices manufactured to deploy the new use. Although one existing licensing exemption was found to be possibly available for catalysts used for HDS of petroleum fuels and one general license was found to be possibly available for catalysts, semiconductors, and electrodes used in hydrogen production or batteries, existing regulations would require most users of products and devices deploying new DU uses to obtain specific source material licenses from the NRC or an Agreement State. This situation would not be improved by pending regulatory modifications. Thus, deployment of new DU uses may be limited because persons having no previous experience with NRC or Agreement State regulations may be hesitant to incur the costs and inconvenience of regulatory compliance, unless using a DU-containing product or device offers a substantial economic benefit over nonradioactive alternatives. Accordingly, estimating the risk of deploying new DU-containing products and devices in certain radiologically uncontrolled areas is recommended. If the estimated risks of such deployment are found to be acceptable, then it may be possible to justify adding new exemptions or general licenses to the NRC regulations.
\end{abstract}




\section{BACKGROUND}

The U.S. Department of Energy (DOE) is funding a depleted uranium (DU) uses research and development $(\mathrm{R} \& \mathrm{D})$ program. Among other things, this program implements the conclusion in the draft DUF $_{6}$ Materials Use Roadmap (DOE 2000) that basic research investigations should be conducted to evaluate the feasibility, impacts, and economics of new beneficial uses for depleted uranium hexafluoride $\left(\mathrm{DUF}_{6}\right)$ conversion products. New beneficial uses for $\mathrm{DUF}_{6}$ conversion products for which investigations are under way as part of the DU uses R\&D program include as catalysts (for destroying volatile organic compounds [VOCs] in off-gases from industrial processes and for hydrodesulfurization [HDS] of petroleum fuels), semiconductors (for fabricating integrated circuits, solar cells, or thermoelectric devices, especially if such articles are expected to have service in hostile environments), and electrodes (for service in solid oxide fuel cells [SOFCs], in photoelectrochemical [PEC] cells used to produce hydrogen, and in batteries).

The draft DUF $F_{6}$ Materials Use Roadmap recognized that institutional influences, particularly the applicable regulatory structure, could affect the feasibility and economics of such new beneficial uses for $\mathrm{DUF}_{6}$ conversion products. Therefore, the DU uses R\&D program includes a regulatory analysis task to (1) evaluate how the existing regulatory structure and pending modifications to it that the U.S. Nuclear Regulatory Commission (NRC) is currently considering would affect full deployment of the DU uses for which research is underway; (2) assess whether additional changes to the statutory and regulatory structure could be risk-justified, if such changes are needed to support full deployment of new beneficial DU uses; and (3) provide a basis for evaluating whether DOE should invest further in basic research to support new beneficial uses of DU within radiologically uncontrolled areas.

\section{PURPOSE}

This report addresses the first aspect of the DU uses R\&D program regulatory analysis task, namely evaluating how the existing regulatory structure and pending modifications to it that the NRC is currently considering would affect full deployment of new beneficial DU uses. To accomplish this purpose, the report characterizes the existing regulatory structure applicable to new beneficial DU uses and identifies ongoing federal agency regulatory development activities that may change the

structure. Possible effects of the existing and modified regulatory structures on full deployment of DU-containing products and devices are discussed. 


\section{EXISTING REGULATORY STRUCTURE}

Figure 1 illustrates the regulated pathways by which DUF $_{6}$ conversion products are expected to move from the DOE-controlled conversion facility to new beneficial uses in radiologically uncontrolled areas and, ultimately, to disposal. These pathways include (1) transfer of DUF ${ }_{6}$ conversion products primarily in the form of depleted uranium oxides from the conversion facility to a non-DOE manufacturing facility; (2) manufacture of DU-containing devices and products; (3) transfer of DU-containing devices and products to users in areas not otherwise required to be radiologically controlled; (4) use of DU-containing devices and products within areas not otherwise required to be radiologically controlled; and (5) disposal of DU-containing devices or products at the end of their useful lives.

Table 1 identifies the existing regulatory structure applicable to the pathways shown in Figure 1. The remainder of this report analyzes in detail the regulatory structure applicable to pathways 2 through 5. A discussion of the regulations applicable to converting DUF $_{6}$ (pathway 1) is beyond the scope of this report. Also beyond the scope of this report are a discussion of regulations applicable to using any $\mathrm{DUF}_{6}$ conversion product that is not being investigated as part of the DU uses $R \& D$ program and a discussion of regulations applicable to using DU-containing products and devices in radiologically controlled areas.

\subsection{TRANSFER OF DU FROM A DOE-CONTROLLED CONVERSION FACILITY TO A NON-DOE MANUFACTURING FACILITY}

The transfer of $\mathrm{DUF}_{6}$ conversion products from a DOE-controlled conversion facility to a non-DOE manufacturing facility would be governed by directive DOE M 474.1-1A, "Manual for Control and Accountability of Nuclear Materials" and Title 10, Part 40 of the Code of Federal Regulations (CFR), "Domestic Licensing of Source Material." The DOE directive requires that before transferring any DU conversion product to a non-DOE manufacturing facility, the conversion facility must verify that the manufacturing facility has authorization to accept the DU [DOE M 474.1-1A, II.5.a(1), November 22, 2000]. To document such verification, the conversion facility must obtain a copy of the manufacturing facility's NRC- or Agreement State-issued specific license authorizing ownership, receipt, possession, and use of DU. 


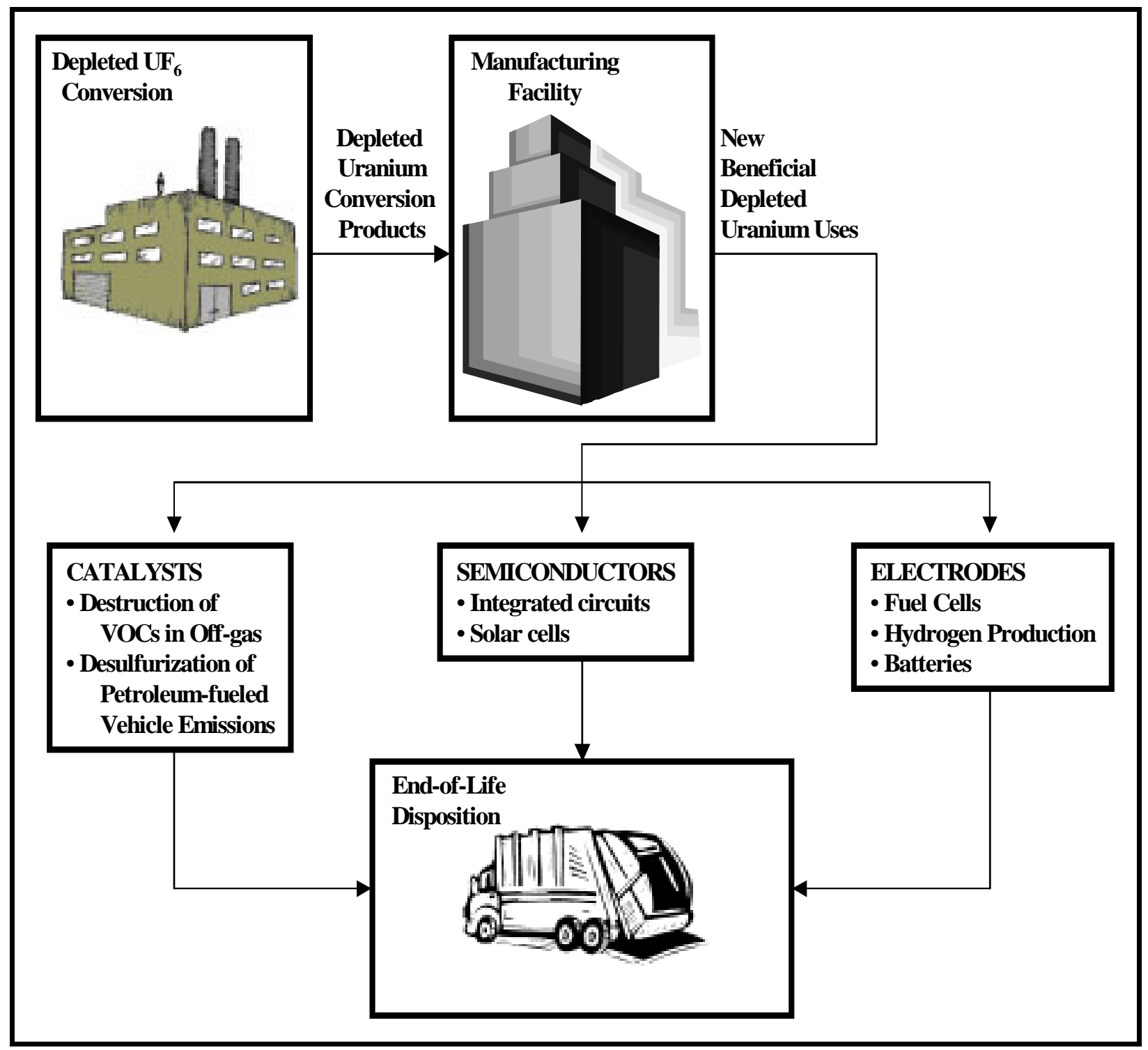

FIGURE 1 Pathway from DUF 6 Conversion to End-of-Life Disposition

\subsection{MANUFACTURE OF INDUSTRIAL PRODUCTS AND DEVICES CONTAINING DU AND TRANSFERS OF THESE PRODUCTS AND DEVICES TO USERS}

\subsubsection{Manufacturing Process}

Because DU is source material, a non-DOE manufacturing facility producing industrial devices and products containing DU would be required to obtain a specific source material license issued by the NRC or an Agreement State pursuant to 10 CFR Part 40. However, if a manufacturing 
TABLE 1 Overview of Existing Regulatory Structure

\begin{tabular}{lll}
\hline \multicolumn{1}{c}{ Pathway } & \multicolumn{1}{c}{ Authority } \\
\hline $\begin{array}{l}\text { Transfer of depleted } \\
\text { uranium (DU) from a } \\
\text { DOE-controlled } \\
\text { conversion facility to a } \\
\text { non-DOE manufacturing } \\
\text { facility }\end{array}$ & $\begin{array}{l}\text { Directive DOE M 474.1, } \\
\text { "Manual for Control and } \\
\text { Accountability of Nuclear } \\
\text { Materials" }\end{array}$ \\
& $\begin{array}{l}\text { Title 10, Part 40, of the Code of } \\
\text { Federal Regulations (10 CFR } \\
\text { Part 40), "Domestic Licensing } \\
\text { of Source Material," or } \\
\text { equivalent Agreement State } \\
\text { regulations }\end{array}$
\end{tabular}

2. Manufacture by a non-DOE manufacturing facility of industrial products and devices containing DU

3. Transfer by a non-DOE manufacturing facility of industrial products and devices containing DU to a user

4. Use of products or devices containing DU

5. Transfer or disposal of DU-containing products and devices by a user
10 CFR Part 40 or equivalent Agreement State regulations

10 CFR 40.51;

10 CFR 150.15(a)(6)

10 CFR Part 40 or equivalent Agreement State regulations

10 CFR 40.51

Exempt users may transfer or dispose of DU-containing products and devices without restrictions.

Licensed users must transfer and dispose of DU-containing products or devices in accordance with 10 CFR 40.51. 
facility expects to transfer the DU-containing devices or products to persons whose subsequent possession, use, transfer, and disposal of these items are exempt from licensing and other regulatory requirements, then only the NRC can issue a license for the transfer, even if the facility is located in an Agreement State [10 CFR 150.15(a)(6)]. In this circumstance, a separate specific source material license also may be required from the Agreement State for the receipt, possession, and use of DU in association with manufacturing. In general, the process for obtaining a specific license involves submission of an application, payment of a fee, review of the application by the NRC or a responsible Agreement State, provision of an opportunity for public involvement, and issuance of the license (see Appendix A).

\subsubsection{Transfers to Users}

Users of DU-containing products and devices that are the focus of this report are expected to be non-DOE persons located in areas not currently under radiological controls. Existing NRC regulations allow an NRC- or an Agreement State-licensed facility that manufactures DU-containing

products or devices to transfer them to the following persons without prior approval, unless the facility's license provides otherwise [10 CFR 40.51(b)]:

\section{DOE;}

2. The agency that regulates radioactive materials in any Agreement State;

3. Any person exempt from NRC or Agreement State licensing requirements, to the extent allowed under the exemption;

4. Any person authorized to receive DU under the terms of a specific or general license issued by the NRC or an Agreement State;

5. Any person abroad pursuant to an export license issued under $10 \mathrm{CFR}$ Part 110, "Export and Import of Nuclear Equipment and Material;" and

6. Any other person with written authorization from the NRC.

On the basis of the above list, the only users not currently under radiological controls to whom DU-containing products and devices could be transferred without first implementing some future controls would be the persons exempt from licensing requirements described in item 3 , or persons covered by certain general licenses described in item 4 . The information provided below better defines these potential users. 


\subsubsection{Existing Exemptions}

Table 2 lists existing exemptions from source material licensing requirements that could apply to DU. The regulations also allow the NRC to "grant such exemptions from the requirements of the regulations ... as it determines are authorized by law and will not endanger life or property or the common defense and security and are otherwise in the public interest" [10 CFR 40.14(a)]. However, the NRC does not use this case-specific exemption to authorize exemptions from requirements to obtain a license (NRC 1981). Rather, it serves as a mechanism for NRC licensees to obtain relief from specific requirements, and its use is generally limited to unique situations (NRC 2000b).

TABLE 2 Existing Exemptions from NRC and Agreement State Source Material Licensing Requirements

Reference

(10 CFR) Description of Exemption

40.13(a) Chemical mixture, compound, solution, or alloy containing $<0.05$ percent by weight of source material

40.13(c)(2)(i) Glazed ceramic tableware containing < 20 percent by weight of source material

40.13(c)(2)(ii) Piezoelectric ceramic containing not more than 2 percent by weight of source material

40.13(c)(2)(iii) Glassware containing not more than 10 percent by weight source material, but not including commercially manufactured glass brick, pane glass, ceramic tile, or other glass or ceramic used in construction

40.13(c)(3) Photographic film, negatives, and prints containing uranium or thorium

40.13(c)(5) Uranium contained in counterweights installed in aircraft, rockets, projectiles, and missiles

40.13(c)(6) Natural or depleted uranium metal used as shielding constituting part of any shipping container

40.13(d) Detector heads for use in fire detection units, provided that each detector head contains not more than 0.005 microcurie of uranium 


\subsubsection{Existing General Licenses}

General licenses are granted by the NRC or Agreement State regulations and are effective without the filing of applications or the issuance of licensing documents to particular persons, although some general licensees must register with the responsible agency. The existing NRC regulations grant the general licenses listed in Table 3. The general license covering industrial products and devices in which DU is used for the purpose of providing a concentrated mass in a small volume (10 CFR 40.25) appears as if it might be available to some DU-containing products and devices that deploy new DU uses. However, it actually would not be available because such products or devices would not use DU for the required purpose. Of the remaining existing general licenses, only one would be potentially available to users of new DU-containing products and devices: the general license to receive, possess, use, and transfer small quantities of source material for research, development, educational, commercial, or operational purposes (i.e., 10 CFR 40.22).

\section{TABLE 3 Existing General Licenses for Source Material}

Reference

(10 CFR)

40.21

40.22

40.23

40.25

40.26

40.27

40.28 .
Description of General License

General license to receive title to source material

General license to receive, possess, use, and transfer small quantities of source material for research, development, educational, commercial, or operational purposes

General license for carriers of transient shipments of natural uranium other than in the form of ore or ore residue

General license to receive, acquire, possess, use, or transfer depleted uranium contained in industrial products or devices for the purpose of providing a concentrated mass in a small volume of the product or device

General license to receive title to, own, or possess by-product material (which means uranium or thorium tailings or waste for the purpose of this exemption)

General license for custody and long-term care of residual radioactive material disposal sites under Title I of the Uranium Mill Tailings Radiation Control Act of 1978, as amended

General license for the custody of and long-term care of uranium or thorium mill tailings sites closed under Title II of the Uranium Mill Tailings Radiation Control Act of 1978, as amended 
Although the general license in 10 CFR 40.22 may be available to DU-containing products and devices that would deploy several of the new DU uses being studied under the DU uses R\&D program, it has some important limitations. First, it expressly applies only to commercial and industrial firms, research, educational and medical institutions, and federal, state, and local government agencies. Accordingly, individual consumers cannot qualify for this general license. Second, the use and transfer of source material is limited to $15 \mathrm{lb}$ at any one time, and a person authorized to use or transfer source material may not receive a total of more than $150 \mathrm{lb}$ in any one calendar year. Finally, the purposes for which source material may be used under this general license are limited to research, development, educational, commercial, or operational purposes. Despite these limitations, this general license has an advantage in that there is no obligation for the licensee to register with the NRC. Furthermore, general licensees under 10 CFR 40.22 would be exempt from the radiological control requirements in 10 CFR Parts 19, 20, and 21. Part 19 establishes requirements for notices, instructions, and reports by licensees to their workers regarding radiological working conditions; Part 20 establishes standards for protection of workers and the public against ionizing radiation resulting from licensed activities, including disposal of radioactive materials; and Part 21 requires anyone involved with a licensed facility to immediately notify the $\mathrm{NRC}$ if they become aware that a facility component is defective or fails to comply with the requirements of the Atomic Energy Act of 1954 (AEA) (AEA 1954).

\subsection{NEW USES OF DU IN RADIOLOGICALLY UNCONTROLLED AREAS}

Uses of DU for which preliminary research is under way as part of the DU uses R\&D program include catalysts (for destroying VOCs in off-gases from industrial processes and for HDS of petroleum fuels), semiconductors (for fabricating integrated circuits, solar cells, or thermoelectric devices, especially if such articles are expected to have service in hostile environments), and electrodes (for service in SOFCs, in PEC cells used to produce hydrogen, and in batteries). This section describes each of these uses and analyzes whether existing licensing exemptions and general licenses would be available to users of products and devices manufactured to deploy each use in areas that are not already radiologically controlled. Table 4 (see Section 3.3.7) summarizes the results of this analysis.

\subsubsection{Catalysts That Destroy Volatile Organic Compounds}

The DU uses R\&D program is investigating new types of uranium oxide catalysts fabricated from DU for destroying volatile organic compounds (VOCs), including alkanes, aromatics, and chlorinated organic compounds. These VOCs occur in off-gases from a variety of industrial processes and may require control to meet air quality emission standards. It is believed that highly active and selective DU oxide catalysts having the potential to decompose them can be synthesized.

For this use, DU oxide catalysts would be fabricated under an NRC and/or Agreement State specific source material license obtained by the manufacturing facility as described in Section 3.2.1. 
Presumably, the catalysts would be assembled at the same facility into systems having the size(s) and configuration(s) necessary for installation into target off-gas streams. The facility would then transfer the catalyst systems to other industrial facilities for use in destroying VOCs in off-gas streams (see 10 CFR 40.51).

The chemical composition of the catalysts and the sizes of the DU oxide catalyst systems that would be transferred to users when this new use of DU is deployed are not presently known. However, DU oxide catalyst systems are not expected to be used to control VOC emissions from consumer products such as automobiles. Rather, it is expected that most of the systems would be configured for installation into exhaust system piping at industrial facilities such as oil refineries or paint factories. These DU oxide catalyst systems might consist of a 4- to 6-in.-diameter steel pipelike housing that is less than $2 \mathrm{ft}$ long and into which catalyst-bearing material has been installed in the form of packing or a lattice insert. The catalyst-bearing material may be particles or a rigid substrate onto which the DU oxide catalyst has been deposited in a very thin layer. In this configuration, each catalyst system would contain less than $15 \mathrm{lb}$ of DU oxide. Also, preliminary data indicate that DU oxide catalysts fabricated for removing VOCs would contain DU in concentrations exceeding 0.05 percent by weight. On the basis of these assumptions, unless further research indicates that DU oxide catalysts can remove VOCs effectively with lower DU concentrations than currently are being studied, DU oxide catalyst systems used to remove VOCs would not qualify for the exemption in 10 CFR 40.13(a). Also, DU oxide catalyst systems used for VOC removal would not fit within the product descriptions for any of the other available exemptions listed in Table 2. Therefore, DU oxide catalyst systems used for VOC removal would not qualify for any existing exemption.

It is possible that a DU oxide catalyst system for VOC removal could qualify for the existing general license in 10 CFR 40.22, if the system would contain less than $15 \mathrm{lb}$ of DU oxide, and the user would not be receiving a total of more than $150 \mathrm{lb}$ of DU oxide in a calendar year to operate the system. Some of the expected users may qualify for this exemption if they consume only a few DU catalyst systems per year. Others who require enough systems annually that they would receive over $150 \mathrm{lb}$ of DU oxide during the year would not qualify for the exemption. It should be noted that, in any event, an individual consumer could not qualify for this exemption, because the general license in 10 CFR 40.22 is only available to commercial and industrial firms; research, educational, and medical institutions; and federal, state, and local government agencies.

If none of the existing exemptions from licensing or general licenses would be available to the user of a DU oxide catalyst system for VOC removal, existing regulations would require that a user seek a specific source material license, as described in Appendix A.

\subsubsection{Catalysts Used for Hydrodesulfurization of Petroleum Fuels}

With worldwide fossil fuel consumption growing rapidly, the removal of sulfur from petroleum fuels is a primary concern. Accordingly, the DU uses R\&D program is evaluating the 
reactivity of DU oxide surfaces with key sulfur-containing compounds relevant to HDS of petroleum fuels.

For use in HDS of petroleum fuels, DU oxide catalysts would be fabricated at a manufacturing facility under an NRC and/or Agreement State specific source material license obtained as described in Section 3.2.1. Under its specific source material license, the manufacturer would transfer the catalysts in varying quantities to the petroleum refining industry for use in catalytic bed reactors. Individual consumers are not expected to be users of DU oxide catalysts for HDS of petroleum fuels.

The chemical composition and physical configuration of the DU oxide catalysts that may be transferred to users when this new use of DU is deployed are not yet known. It is possible that the exemption for using chemical mixtures, compounds, solutions, or alloys containing less than 0.05 percent by weight of source material [10 CFR 40.13(a)] could apply. However, preliminary data indicate that DU oxide catalysts fabricated for HDS of petroleum fuels would contain DU in concentrations exceeding 0.05 percent by weight. Therefore, unless further research indicates that DU oxide catalysts can achieve HDS of petroleum fuels effectively with lower DU concentrations than currently are being studied, DU oxide catalyst systems used for HDS of petroleum fuels would not qualify for the exemption in 10 CFR 40.13(a). In addition, a review of the other existing exemptions from NRC licensing requirements that could apply to DU uses (see Table 2) suggests that using DU oxide catalysts in catalytic bed reactors for HDS of petroleum fuels would not qualify for any of these exemptions.

The general license in 10 CFR 40.22 would not be available to users of DU oxide catalyst systems for HDS of petroleum fuels if more than $15 \mathrm{lb}$ of DU oxide would be needed at any one time, or if the user would receive more than $150 \mathrm{lb}$ of DU oxide in a calendar year. While it is possible that some users of DU oxide catalytic bed reactors in the petroleum refining industry might meet these criteria, it seems more likely that users would require larger quantities.

If none of the existing exemptions from licensing requirements or general licenses would be available to DU oxide catalyst systems for HDS of petroleum fuels, existing regulations would require a user to obtain a specific source material license, as described in Appendix A.

\subsubsection{Semiconductors}

Semiconductors are used extensively in electronic devices of all kinds, which are pervasive in the world today. The materials most often used to fabricate semiconductors are silicon ( $\mathrm{Si}$ ), gallium arsenide (GaAs), and germanium (Ge). However, early investigations suggest that, in comparison to these conventional semiconductor materials, uranium oxide-based semiconductors could operate at substantially higher temperatures and more effectively resist radiation and electromagnetic fields. Accordingly, the DU uses R\&D program is characterizing the semiconductive properties of DU oxide in anticipation that DU oxide-based semiconductors may be well suited for 
use in products such as integrated circuits, solar cells, or thermoelectric devices, especially if those products are expected to have service in hostile environments, such as outer space and high radiation areas.

DU oxide semiconductors would be manufactured under an NRC or Agreement State specific source material license obtained as described in Section 3.2.1. While it is possible that a DU oxide semiconductor manufacturer would also manufacture electronic devices that incorporate such semiconductors, for the purpose of this report it is assumed that the semiconductor manufacturer would transfer the fabricated semiconductors to other manufacturers who would use them to make various electronic products. The latter manufacturers would also need to obtain NRC and/or Agreement State specific source material licenses as described in Section 3.2.1. Such licenses would cover receipt, possession, and use in the manufacturing process of DU oxide semiconductors, as well as transfer of DU-containing electronic products to users.

The size and number of DU oxide semiconductor chips that may be transferred to a user as integral components of DU-containing electronic devices are not presently known. However, DU oxide semiconductors are expected to contain greater than 0.05 percent by weight of source material. On the basis of this assumption, DU oxide semiconductors would not qualify for the exemption in 10 CFR 40.13(a). Also, DU oxide semiconductors would not fit within the product descriptions for any of the other available exemptions listed in Table 2. Therefore, neither DU oxide semiconductors nor the electronic products that contain them would qualify for any existing exemption listed in Table 2.

It is possible that a user of electronic devices containing DU oxide semiconductors could qualify for the existing general source material license in 10 CFR 40.22. This could occur if the user would store or utilize parts or devices containing less than $15 \mathrm{lb}$ of DU oxide, and would not receive parts or devices in a calendar year containing a total of more than $150 \mathrm{lb}$ of DU oxide. It should be noted, however, that an individual consumer could not qualify, because the general license in 10 CFR 40.22 is only available to commercial and industrial firms; research, educational, and medical institutions; and federal, state, and local government agencies.

If none of the existing exemptions from licensing requirements or general licenses would be available to DU oxide semiconductors, existing regulations would require a user to obtain a specific source material license using the process described in Appendix A.

\subsubsection{Electrodes Used in Fuel Cells}

Fuel cells convert chemical energy directly into electricity. Numerous types of fuel cells have been manufactured, but the SOFC is the most likely contender for compact generators capable of locally producing electric power in a range from a few kilowatts to a few megawatts. In SOFCs, the anode, cathode, and electrolyte are all made from ceramic substances, which allows for operation at very high temperatures. This offers significant advantages over conventional electrical energy 
sources, such as much higher efficiency, significantly less environmental pollution, and direct load following capability. One existing design for SOFCs uses an array of meter-long tubes. Another includes stacks of compressed discs that resemble compact discs. Current SOFC technology is limited by relatively poor oxide ion conductivity, and erosion of the electrodes and electrolyte due to surface interactions and differences of the thermal expansion of different materials at the electrode/electrolyte interface. The DU uses R\&D program is studying the ability of uranium oxide films to provide solutions to these problems when used in the fabrication of SOFC electrodes.

DU-containing SOFCs would be manufactured under an NRC and/or Agreement State specific source material license obtained as described in Section 3.2.1. The physical configuration of the DU-containing SOFCs that may be transferred to users when this new beneficial use of DU is deployed is not yet known. However, it is likely that DU-containing SOFCs will be similar in design and size to existing SOFCs. Also, the DU material in DU-containing SOFCs is expected to contain greater than 0.05 percent by weight of source material. On the basis of these expectations, DU-containing SOFCs would not qualify for the exemption in 10 CFR 40.13(a). Also, DU-containing SOFCs would not fit within the product descriptions for any of the other available exemptions listed in Table 2. Therefore, DU-containing SOFCs would not qualify for any of the existing exemptions listed in Table 2.

DU-containing SOFCs also would not qualify for the existing general source material license in 10 CFR 40.22 because a system, while compact, would surely either contain more than $15 \mathrm{lb}$ of DU oxide or need to receive a total of more than $150 \mathrm{lb}$ of DU oxide in a calendar year to continue operating.

If none of the existing exemptions from licensing requirements or general licenses would be available to DU-containing SOFCs, existing regulations would require users to obtain a specific source material license, as described in Appendix A.

\subsubsection{Electrodes Used in the Production of Hydrogen}

Hydrogen is a premium quality energy carrier and storage medium that can be used with very high efficiency and zero emissions. Accordingly, scientists are investigating many hydrogen production processes. One that has shown promise is the photo-assisted dissociation of water into hydrogen and oxygen as a result of sunlight striking the photoanode in a PEC cell. This process provides a direct method for converting optical energy into chemical form. However, stability of the PEC cell photoanode has proven to be a crucial problem in the realization of workable PEC cell devices. Pure uranium dioxide $\left(\mathrm{UO}_{2}\right)$ is one of the few oxide semiconductors that has been identified as being sufficiently stable to withstand photoanodic dissolution. Therefore, the DU uses R\&D program is studying the photoanode characteristics of undoped depleted $\mathrm{UO}_{2}$ in fused polycrystalline ceramic forms to determine their viability for use in PEC cell photoanodes. The primary use expected for hydrogen-producing PEC cells would be as components in a variety of local energy production systems. 
DU-containing PEC cells would be manufactured under an NRC and/or Agreement State specific source material license obtained as described in Section 3.2.1. Presumably, for local energy production systems, some as yet unknown number of PEC cells would be combined into an array at the manufacturing facility and transferred to the user as a unit. The physical size and configuration of the unit are not yet known, and comparable systems made from other materials also are not yet available as a basis for estimation. Nevertheless, the DU material in DU-containing PEC cells is expected to contain greater than 0.05 percent by weight of source material. On the basis of this expectation, local energy production units composed of such DU-containing PEC cells would not qualify for the exemption in 10 CFR 40.13(a). Also, local energy production units composed of DU-containing PEC cells would not fit within the product descriptions for any of the other available exemptions listed in Table 2. Therefore, such units would not qualify for any of the existing exemptions listed in Table 2.

Local energy production units composed of DU-containing PEC cells also would not qualify for the general license in 10 CFR 40.22 if the unit containing PEC cells would contain more than $15 \mathrm{lb}$ of DU oxide at any one time, or if the user would be receiving more than $150 \mathrm{lb}$ of DU oxide in a calendar year in order to operate the system. It is possible that some users of local energy production units might meet these criteria. However, it seems likely that the most probable users, such as industrial facilities, hospitals, or commercial buildings, would require larger quantities of DU oxide. Also, it should be noted that an individual consumer could not qualify for the general license in 10 CFR 40.22, because it is only available to commercial and industrial firms; research, educational, and medical institutions; and federal, state, and local government agencies.

If none of the existing exemptions from licensing requirements or general licenses would be available to local energy production units composed of DU-containing PEC cells, existing regulations would require a user to obtain a specific source material license using the process described in Appendix A.

\subsubsection{Electrodes Used in Batteries}

The DU uses R\&D program is studying the electrochemical properties of uranium dioxide and plans to develop a rechargeable, uranium-based battery using DU oxide. DU-containing batteries would be manufactured under an NRC and/or Agreement State specific source material license obtained as described in Section 3.2.1. The physical size and configuration of a DU-containing battery that would be transferred to a user when this new use of DU is deployed are not yet known. However, it is likely that DU-containing batteries would be similar in design and size to batteries currently made of other materials that are used in applications similar to those expected for DU-containing batteries (e.g., uninterruptible or emergency power supplies for industrial, military, or commercial applications and hospitals). Also, the DU material in DU-containing batteries is expected to contain greater than 0.05 percent by weight of source material. On the basis of these expectations, DU-containing batteries would not qualify for the exemption in 10 CFR 40.13(a). DU-containing batteries also would not fit within the product descriptions for any of the other 
available exemptions listed in Table 2. Therefore, DU-containing batteries would not qualify for any of the existing exemptions listed in Table 2.

The general source material license in 10 CFR 40.22 also would not be available if DU-containing batteries would contain more than $15 \mathrm{lb}$ of DU oxide at any one time, or if the user would be receiving more than $150 \mathrm{lb}$ of DU in a calendar year. It is possible that some users of DU-containing batteries might meet these criteria. However, it seems likely that the most probable users, such as industrial, military, or large commercial facilities, and hospitals, would require larger quantities of DU oxide. Also, it should be noted that an individual consumer could not qualify for the general license in 10 CFR 40.22, because it is only available to commercial and industrial firms; research, educational, and medical institutions; and federal, state, and local government agencies.

If none of the existing exemptions from licensing requirements or general licenses would be available to DU-containing batteries, existing regulations would require a user to obtain a specific source material license using the process described in Appendix A.

\subsubsection{Summary}

Sections 3.3.1 through 3.3.6 describe the new DU uses being studied under the DU uses R\&D program and analyze whether existing licensing exemptions and general licenses would be available to users of products and devices manufactured to deploy each use. Table 4 summarizes the results of these analyses. Although accessible information is insufficient to rule out the availability of certain existing licensing exemptions and general licenses for a few new DU uses, Table 4 illustrates that the vast majority of existing licensing exemptions and general licenses in 10 CFR Part 40 would not be available to the products and devices that would deploy new DU uses being studied under the DU uses R\&D program. Therefore, under existing regulations, most users of such products and devices would be required to obtain a specific source material license using the process described in Appendix A.

\subsection{END-OF-LIFE DISPOSITION}

The Nuclear Waste Policy Act of 1982 (NWPA) (NWPA 1983) and the Low-Level Radioactive Waste Policy Amendments Act of 1985 (LLRWPAA) (LLRWPAA 1986) define categories of radioactive waste, including high-level radioactive waste, spent nuclear fuel, transuranic waste, and low-level radioactive waste (LLW). Such definitions have been either adopted by reference, or codified in NRC regulations. In general, depleted uranium oxides would be lowlevel radioactive waste when discarded. Therefore, at the end of the useful life of an industrial product or device containing depleted uranium, either the depleted uranium component must be removed and reused or recycled, or the article must be managed for disposal in accordance with NRC regulations in 10 CFR Parts 20 ("Standards for Protection Against Radiation") and 61 ("Licensing Requirements for Land Disposal of Radioactive Wastes”) or equivalent Agreement State regulations. 
TABLE 4 Availability of Existing NRC or Agreement State Exemptions and General Licenses to Users of New DU Products and Devices in Radiologically Uncontrolled Areas

\begin{tabular}{|c|c|c|c|c|c|c|}
\hline Exemption & 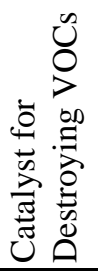 & 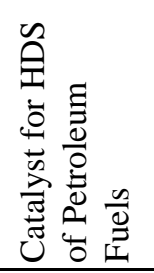 & 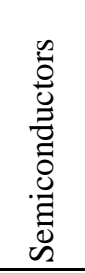 & 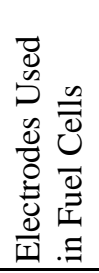 & 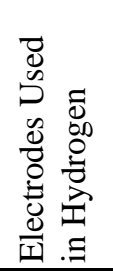 & 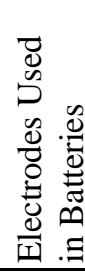 \\
\hline $\begin{array}{l}\text { Chemical mixture, compound, solution, or } \\
\text { alloy containing }<0.05 \text { percent by weight of } \\
\text { source material }[10 \text { CFR } 40.13 \text { (a) }]\end{array}$ & $\mathrm{NA}^{\mathrm{a}}$ & $\mathrm{PA}^{\mathrm{b}}$ & NA & NA & NA & NA \\
\hline $\begin{array}{l}\text { Glazed ceramic tableware containing } \\
<20 \text { percent by weight of source material } \\
{[10 \text { CFR } 40.13(\mathrm{c})(2)(\mathrm{i})]}\end{array}$ & NA & NA & NA & NA & NA & NA \\
\hline $\begin{array}{l}\text { Piezoelectric ceramic containing not more } \\
\text { than } 2 \text { percent by weight of source material } \\
\text { [10 CFR } 40.13(\mathrm{c})(2)(\mathrm{ii})]\end{array}$ & NA & NA & NA & NA & NA & NA \\
\hline $\begin{array}{l}\text { Glassware containing not more than } \\
10 \text { percent by weight source material but not } \\
\text { including commercially manufactured glass } \\
\text { brick, pane glass, ceramic tile, or other glass } \\
\text { or ceramic used in construction } \\
{[10 \text { CFR } 40.13(\mathrm{c})(2)(\mathrm{iii})]}\end{array}$ & NA & NA & NA & NA & NA & NA \\
\hline $\begin{array}{l}\text { Photographic film, negatives, and prints } \\
\text { containing uranium or thorium } \\
{[10 \text { CFR } 40.13(\mathrm{c})(3)]}\end{array}$ & NA & NA & NA & NA & NA & NA \\
\hline $\begin{array}{l}\text { Uranium contained in counterweights } \\
\text { installed in aircraft, rockets, projectiles, and } \\
\text { missiles }[10 \text { CFR } 40.13(\mathrm{c})(5)]\end{array}$ & NA & NA & NA & NA & NA & NA \\
\hline $\begin{array}{l}\text { Natural or depleted uranium metal used as } \\
\text { shielding constituting part of any shipping } \\
\text { container [10 CFR } 40.13(\mathrm{c})(6)]\end{array}$ & NA & NA & NA & NA & NA & NA \\
\hline $\begin{array}{l}\text { Detector heads for use in fire detection units, } \\
\text { provided that each detector head contains not } \\
\text { more than } 0.005 \text { microcurie of uranium } \\
\text { [10 CFR } 40.13(d)]\end{array}$ & NA & NA & NA & NA & NA & NA \\
\hline \multicolumn{7}{|l|}{ General License } \\
\hline $\begin{array}{l}\text { General license to use and transfer small } \\
\text { quantities of source material [10 CFR 40.22]. }\end{array}$ & PA & $\mathrm{PA}$ & $\mathrm{PA}$ & NA & $\mathrm{PA}$ & $\mathrm{PA}$ \\
\hline
\end{tabular}

a $\quad \mathrm{NA}=$ not available.

b $\quad \mathrm{PA}=$ possibly available. 
If the article also contains hazardous waste as defined by the Resource Conservation and Recovery Act (RCRA) [RCRA 1976] [40 CFR 261.3], then it would require management at the end of its useful life in accordance with not only NRC or Agreement State regulations, but also U.S. Environmental Protection Agency (EPA) regulations or the approved hazardous waste regulations of an EPA-authorized state agency, including 40 CFR Parts 264 ("Standards for Owners and Operators of Hazardous Waste Treatment, Storage, and Disposal Facilities") and 270 ("EPA Administered Permit Programs: The Hazardous Waste Management Program"). In addition, the user would be required to comply with the requirements of 40 CFR Part 262, "Standards Applicable to Generators of Hazardous Waste."

Presently, insufficient information is available to confirm whether any products or devices that deploy new DU uses covered by this report would contain a hazardous waste component at the time of disposal. Thus, management of both LLW and low-level mixed waste are discussed below.

\subsubsection{Low-Level Radioactive Waste}

The LLRWPAA assigns states the responsibility to provide for disposal of LLW generated within their borders. It encourages the states to enter into compacts that allow generators in several states to dispose of waste at a joint disposal facility. Most states have entered into such compacts. However, no new disposal facilities have been built since the LLRWPAA was passed (NRC 2002c). At present, three commercially operated LLW disposal facilities accept waste from others, all of which are located in Agreement States. The state-owned LLW facility at Barnwell, South Carolina, accepts waste from all U.S. generators except those in the Rocky Mountain and Northwest Compacts. ${ }^{1}$ Beginning in 2008, Barnwell will only accept waste from Atlantic Compact states. ${ }^{2}$ Barnwell is licensed by the State of South Carolina to receive LLW in Classes A, B, and C. ${ }^{3}$ The LLW facility at Hanford, Washington, which is operated by US Ecology, is licensed by the State of Washington to also accept LLW in Classes A, B, and C; access is restricted, however, to generators in the Northwest and Rocky Mountain Compacts. The Envirocare of Utah facility at Clive, Utah, is licensed by the state to accept uranium and thorium mill tailings and LLW in Class A from generators in all regions. The federal government is responsible for disposal of LLW generated at federal facilities and for LLW with concentrations of radionuclides that exceed the limits for Class C [LLRWPAA 1986, sec. 3(b)(1)]. To meet this responsibility, DOE owns disposal facilities at several locations. However, except in certain cases involving depleted uranium from uranium enrichment

1 The Rocky Mountain Compact consists of Nevada, Colorado, and New Mexico. The Northwest Compact consists of Washington, Oregon, Idaho, Montana, Wyoming, and Utah.

2 The Atlantic Compact consists of Connecticut, New Jersey, and South Carolina.

3 Among other things, 10 CFR Part 61, Subpart D, establishes a classification system for evaluating whether radioactive wastes are suitable for near-surface disposal and for assigning appropriate waste form and stability requirements. This classification system is based on the concentrations in waste of radionuclides listed in $10 \mathrm{CFR}$ Part 61, Tables 1 and 2. Three classes of radioactive waste (A, B, and C) are defined as eligible for near-surface disposal. 
operations, LLW generated by non-DOE activities is not accepted for disposal at these facilities. Thus, under the existing regulatory structure, non-DOE users would not be able to dispose of discarded products and devices that deploy new DU uses in DOE LLW disposal facilities.

Under existing regulations, unless they are mixed wastes, discarded products and devices that deploy the new DU uses covered by this report would be classified as Class A low-level wastes. Therefore, unless covered by one of the exemptions listed in Table 2 or the general license in 10 CFR 40.22, these products and devices would require disposal in a LLW disposal facility licensed by the NRC or an Agreement State.

\subsubsection{Low-Level Mixed Waste}

Currently, commercially available treatment, storage, and/or disposal facilities that are accepting mixed waste of any type are very limited. For disposal, the only commercially available mixed waste unit is located at the Envirocare of Utah facility near Clive, Utah. Therefore, if any product or device that deploys a new DU use covered by this report would be classified as mixed waste at the end of its useful life, it would require disposal at the Envirocare mixed waste unit, unless another mixed waste disposal facility becomes available. DOE owns a few mixed waste disposal facilities that are currently available only for disposal of mixed wastes generated at the federal sites where the facilities are located.

\section{ONGOING FEDERAL REGULATORY DEVELOPMENT ACTIVITIES THAT MAY CHANGE THE EXISTING REGULATORY STRUCTURE}

\subsection{INTRODUCTION}

In 1997, the NRC commissioners directed NRC staff to identify and prioritize areas within its regulations and processes applicable to nuclear materials that "either [are] now, or could be made, amenable to risk-informed, performance-based or risk-informed less prescriptive approaches" (NRC 1997). On the basis of this direction, the NRC staff is proceeding with two ongoing regulatory modification initiatives that are relevant to regulation of new DU uses (NRC 2002a):

- Interagency Jurisdictional Working Group Evaluating the Regulation of LowLevel Source Material Containing Less Than 0.05 Percent by Weight Concentration Uranium and/or Thorium; and

- Rulemaking: Distribution of Source Material to Exempt Persons and to General Licensees and Revision of 10 CFR 40.22 General License. 
These ongoing regulatory modification initiatives and their relevance to the issues discussed in this report are described in more detail below.

\subsection{INTERAGENCY JURISDICTIONAL WORKING GROUP FOR EVALUATING THE REGULATION OF SOURCE MATERIALS CONTAINING LESS THAN O.05 PERCENT BY WEIGHT CONCENTRATION OF URANIUM AND/OR THORIUM}

\subsubsection{Background}

In August 2000, the NRC formed the Interagency Jurisdictional Working Group ${ }^{4}$ for evaluating jurisdictional and technical issues regarding the regulation of materials with low concentrations of uranium and thorium (NRC 2000c). The primary focus of this group has been the possible health and safety need to modify the exemption in 10 CFR 40.13(a) for unimportant quantities of source material. This exemption is currently available to any person who receives, possesses, uses, transfers, or delivers source material in any chemical mixture, compound, solution, or alloy in which the source material is by weight less than 0.05 percent. It excuses the qualified person from the AEA requirement to obtain a license (42 United States Code [U.S.C.] 2092) and from other requirements in 10 CFR Part 40. Apparently, when the exemption was added to the NRC regulations in 1961, 0.05 percent by weight (500 parts per million [ppm]) was set as the lowest source material concentration requiring regulation because it was the lowest concentration in naturally occurring uranium ore at which the ore was considered useful as a source of fissionable material for the production of special nuclear material. At the time, no quantitative consideration was given to whether the unregulated use of substances containing source material at less than $500 \mathrm{ppm}$ would be harmful to public health or safety. Rather, it was assumed that the health and safety impacts of source material were low and that protecting the common defense and security were more significant considerations (NRC 1992).

Health and safety issues associated with the exemption in 10 CFR 40.13(a) arose in 1991 when the NRC revised the standards for radiation protection in 10 CFR Part 20 by decreasing the values for permissible concentrations of radiation in air and water effluents containing uranium and thorium (NRC 1991). Accordingly, the NRC issued an advance notice of proposed rulemaking in 1992 (NRC 1992) requesting information from the regulated community on the type, quantity, and form of source material being managed as exempt under 10 CFR Part 40. When this advance notice failed to produce enough information to serve as the basis for a proposed rule, the NRC postponed making changes to its source material control regulations (NRC 1998). By late 1999, however, the

4 Members of the Interagency Jurisdictional Working Group include individuals on the NRC staff and representatives of the Organization of Agreement States (OAS), Conference of Radiation Control Program Directors (CRCPD), EPA, Occupational Safety and Health Administration (OSHA), DOE, U.S. Army Corps of Engineers, and U.S. Department of Transportation. 
NRC staff had become convinced, on the basis of conservative exposure scenarios and model assumptions, that public health and the environment would not be adequately protected if certain mineral-derived products containing source material at less than $500 \mathrm{ppm}$ (in particular, zircon sand) continued to be exempt from regulation (NRC 1999a,b). Even so, the NRC staff did not want to address the problem by simply lowering the exempt concentration limit for source material. They were concerned that, by doing so, the ubiquitous presence of small concentrations of uranium and thorium in mineral ores could involve the NRC with the regulation of many activities unrelated to the nuclear fuel cycle, such as almost all mineral processing activities. They believed this result would be inconsistent with the NRC's mission. Furthermore, the NRC staff was of the opinion that, if the Commission were to seek out and license these non-fuel-cycle activities, the effort would likely overlap with the efforts of a number of other regulatory agencies, such as the EPA, OSHA, and some state health and environmental regulatory agencies.

\subsubsection{Possible Regulatory Changes and Potential Effects on Existing Regulatory Structure Applicable to New DU Uses}

At a meeting held March 6-7, 2002, members of the Interagency Jurisdictional Working Group discussed the final version of NUREG-1717 (NRC 2001), which suggests that the exemption in 10 CFR 40.13(a) may be unprotective in cases involving certain mineral-derived products containing source material at less than $500 \mathrm{ppm}$ (in particular, zircon sand). After considering the conservative bases on which doses are estimated in NUREG-1717, the Working Group concluded that actual radiation doses to workers and the public in the cases of concern are much lower than reported (NRC 2002c). This conclusion allayed NRC staff concerns that 10 CFR 40.13(a) should be immediately changed. Even so, the members of the Working Group observed that industrial scenarios not evaluated in the NUREG-1717 may exist in which exposures to workers and members of the public would actually be significant. Accordingly, they decided that some oversight of source material now exempt under 10 CFR 40.13(a) should be implemented. The Working Group further determined that the following approach to addressing concerns about the regulatory exemption in 10 CFR 40.13(a) would be reasonable (NRC 2002b):

Decrease NRC responsibility, such that NRC regulates only uranium and thorium extracted for the purposeful use of uranium and thorium. All other uranium and thorium would be considered naturally occurring radioactive material, and could be regulated by the States and the EPA under their current authorities. The exemption in Section 40.13(a) would be eliminated with this option.

The NRC staff was scheduled to deliver a report of the recommendations of the Interagency Jurisdictional Working Group to the NRC commissioners in June 2002 (NRC 2002b). As of November 18, 2002, public access to the report was not available. Although this delay appears to have no direct relationship to it, on November 6, 2002, the NRC announced that proposed regulations will be developed to control slightly radioactive solid materials originating at licensed nuclear facilities (NRC 2002g). Such solid materials may include equipment, metals, concrete, soils, 
trash, and furniture, which are released under existing regulations with varying levels of residual radioactivity determined on a case-by-case basis. While the case-by-case approach has been determined to protect public health and safety, the NRC plans to amend its regulations to provide clearer requirements regarding releases of solid materials containing residual radioactivity. As a starting point for the discussion of alternatives in the rulemaking, which is scheduled for completion within three years, the NRC will put forward 1 millirem per year (mrem/yr) as a possible dose limit for solid material releases (NRC 2002e,f). Even though the final dose limit established in this rulemaking will not apply to materials classified as source material or to products and devices containing such material, the National Academy of Sciences' National Research Council noted in a report to the NRC that consistency among regulations and standards governing releases of radioactivity is desirable (NAS 2002). Therefore, in order to foster such consistency, the NRC commissioners may be delaying action on the recommendations of the Interagency Jurisdictional Working Group until the release standard for slightly radioactive solid materials has been established. If so, rather than eliminating the exemption from licensing and regulatory requirements for substances containing source material at less than $500 \mathrm{ppm}$, the NRC may eventually replace it with an exemption for source material in concentrations that would not expose members of the public to radiation doses above the limit specified for release of slightly radioactive solid materials. For this report, it is not possible to determine whether the NRC is actually considering this approach. Even if the approach is being considered, insufficient information is currently available to predict the likelihood that products or devices manufactured to deploy any new DU use would qualify for the future exemption.

If the NRC simply eliminates the exemption in 10 CFR 40.13(a), as recommended by the Interagency Jurisdictional Working Group, the change should have little impact on the regulatory structure applicable to any of the new DU uses being studied under the DU uses R\&D program. As indicated in Table 4 and discussed in Section 3.3.2, the only new DU use to which the exemption in 10 CFR 40.13(a) might be possibly available is use as a catalyst for HDS of petroleum fuels. Furthermore, the likelihood that products or devices manufactured to deploy this use would actually qualify for the exemption appears small. Therefore, elimination of the exemption from licensing and regulatory requirements for substances containing source material at less than $500 \mathrm{ppm}$ would not significantly increase the number of users of products and devices deploying new DU uses required to obtain specific source material licenses. 


\subsection{RULEMAKING: DISTRIBUTION OF SOURCE MATERIAL TO EXEMPT PERSONS AND TO GENERAL LICENSEES AND REVISION OF 10 CFR 40.22 GENERAL LICENSE}

\subsubsection{Background}

Concurrent with formation of the Interagency Jurisdictional Working Group, the NRC created a Rulemaking Working Group ${ }^{5}$. The mission of the Rulemaking Working Group was to develop a plan for changing 10 CFR Part 40 to be more risk-informed with respect to the distribution of source material to general licensees and persons exempt from licensing (NRC 2000c). The Rulemaking Working Group was directed (NRC 2000a) to consider, during development of its plan, options to resolve the issues raised in a 1999 petition for rulemaking filed by the State of Colorado and the Organization of Agreement States (NRC 1999c). Specifically, the rulemaking plan was to address the petitioners' request that 10 CFR 40.22(b) be modified by removing what the petitioners believed to be a blanket exemption under the general license from the requirements of $10 \mathrm{CFR}$ Parts 19 and 20. ${ }^{6}$ In addition, the Rulemaking Working Group was instructed (NRC 2000a) to initiate development of a proposed rule to amend 10 CFR 40.51(b)(3) and (4), such that prior Commission approval would be needed for all transfers of source material by specific licensees to persons exempt from licensing under 10 CFR 40.13(a).

\subsubsection{Possible Regulatory Changes and Potential Effects on Existing Regulatory Structure Applicable to New DU Uses}

\subsubsection{Changes to 10 CFR 40.22}

At the time the Rulemaking Working Group was formed, the NRC staff was involved in preparing a draft of NUREG-1717 (NRC 1999b). This draft estimated potential and likely doses to workers and the public resulting from activities covered by the existing exemptions and general licenses in 10 CFR Parts 30 and 40. The Rulemaking Working Group used the doses reported in the draft of NUREG-1717 as a basis for its rulemaking plan. The NRC staff submitted this plan to the Commission in April 2001 (NRC 2002a). However, as of September 16, 2002, the Commission had not acted on the NRC staff's recommendations. Furthermore, a member of the NRC staff reports that NRC action on the staff's recommendations is not expected any time soon (Comfort 2002). As a result, a detailed evaluation of the potential effects of the NRC staff's recommended approach, as

5 Members of the Rulemaking Working Group include individuals on the NRC staff and representatives of the OAS and the CRCPD.

6 Respectively, 10 CFR Parts 19 and 20 establish worker protection requirements and radiation protection standards. 
documented in the rule-making plan, on the regulatory structure applicable to new DU uses could not be included in this report. Nevertheless, it can be said that the rulemaking plan discusses five options for modifying the general license in 10 CFR 40.22, which are listed below (Comfort 2002):

1. Make no change to the existing general license (no action).

2. Modify the existing general license to require general licensees under $10 \mathrm{CFR}$ 40.22 to comply with specific provisions of 10 CFR Parts 19, 20, and 21 under certain circumstances, as suggested by the State of Colorado and the OAS in a petition for rulemaking dated May 10, 1999.

3. Require general licensees to report certain information that would help the NRC decide whether protection of workers, the public, and/or the environment warrants more controls under 10 CFR 40.22.

4. Reduce the threshold amounts defining how much source material a general licensee under 10 CFR 40.22 may use and transfer at one time, or may receive during a year, before a specific license is required.

5. Establish increasing threshold amounts of source material to define tiers of general licensees under 10 CFR 40.22, with each tier being subject to more radiation protection requirements than the preceding tier, until a specific source material license becomes mandatory.

Section 3 concludes that the existing general license in 10 CFR 40.22 would be possibly available to five of the new DU uses (see Table 4): catalyst for destroying VOCs; catalyst for HDS of petroleum fuels; semiconductors; electrodes used in hydrogen production; and electrodes used in batteries. Because existing exemptions and other general licenses would not be available to the vast majority of new DU uses being studied under the DU uses R\&D program, any changes to $10 \mathrm{CFR}$ 40.22 have more potential to alter the existing regulatory structure applicable to users of products or devices manufactured to deploy new DU uses than proposed regulatory changes discussed in other sections of this report. In general, the options being considered for changing 10 CFR 40.22 would subject general licensees to certain radiation protection requirements in 10 CFR Parts 19, 20, and 21 for the first time.

\subsubsection{Changes to 10 CFR 40.51}

On August 28, 2002, a notice was published in the Federal Register (NRC 2002d) proposing to amend $10 \mathrm{CFR} 40.51$ so that NRC licensees would be required to obtain prior written NRC approval before transferring source material to any person exempt from licensing under 10 CFR 40.13(a), including a disposal facility. According to the notice of proposed rulemaking, a licensee seeking to obtain such prior NRC approval would be required to submit a dose assessment 
with information containing the estimated annual total effective dose equivalent to a member of the public that would result from the transfer, and the parameters and assumptions used in the estimate. If the NRC promulgates this proposed change to 10 CFR 40.51, the regulatory structure applicable to the manufacture and use of products or devices that deploy new DU uses being studied in the DU uses R\&D program would not be significantly different from the applicable regulatory structure under existing regulations. As indicated in Table 4, the only new DU use to which the existing exemption in 10 CFR 40.13(a) would be possibly available is use as a catalyst for HDS of petroleum fuels. Also, as indicated in Section 3.3.2, most DU-containing catalysts for HDS of petroleum fuels are expected to contain DU in excess of $500 \mathrm{ppm}$, which would disqualify them for the exemption. Therefore, it is likely that most users of DU-containing catalyst systems for HDS of petroleum fuels would not qualify for the existing exemption in 10 CFR 40.13(a). Accordingly, the proposed change would affect the requirements applicable to the transfer activities of almost no products and devices that deploy new DU uses.

If a DU-containing catalyst system for HDS of petroleum fuels did qualify for exempt use under the existing 10 CFR 40.13(a), then manufacturers of the system would be required under the proposed 10 CFR 40.51 to perform a dose assessment and obtain NRC approval before transferring the system to any exempt user. However, the proposed modification of 10 CFR 40.51 would not subject exempt users themselves to additional requirements.

\subsection{SUMMARY}

In 1997, the NRC directed its staff to identify areas within its regulations that would be amenable to a more risk-informed approach. On the basis of this direction, the NRC staff is proceeding with two initiatives that are relevant to regulation of new DU uses. As part of the first initiative, an Interagency Jurisdictional Working Group was formed to evaluate whether there is a health and safety need to modify the exemption from licensing and other regulatory requirements in 10 CFR 40.13(a). As a result of this evaluation, the Jurisdictional Working Group determined that it would be reasonable to eliminate the exemption in 10 CFR 40.13(a) and decrease NRC responsibility to the regulation of only uranium and thorium extracted for the purposeful use of uranium and thorium. All other uranium and thorium would be considered naturally occurring radioactive material and could be regulated by the States and the EPA. This change would not significantly increase the number of users of products and devices deploying new DU uses required to obtain specific source material licenses under the existing regulatory structure.

The NRC may be considering an alternative approach that would not simply eliminate the exemption in 10 CFR 40.13(a), as recommended by the Interagency Jurisdictional Working Group. Rather, it is possible that the NRC may create a new exemption for source material in concentrations that would not expose members of the public to radiation doses above a limit specified in a separate rulemaking for release of slightly radioactive solid materials. Even so, insufficient information is currently available to include in this report a prediction of the likelihood that products or devices manufactured to deploy any new DU use would qualify for such a future exemption. 
As part of the second initiative, a Rulemaking Working Group was formed to develop a plan for changing 10 CFR Part 40 to be more risk-informed with respect to the distribution of source material to general licensees and persons exempt from licensing. The Rulemaking Working Group developed a plan for modifying 10 CFR 40.22 such that general licensees under that section would no longer be exempt from all radiation protection requirements. The NRC commissioners have not yet approved the rulemaking plan. However, assuming that they eventually do so, the modifications to 10 CFR 40.22 may impose radiation protection standards on products and devices that would deploy as many as five of the new DU uses being studied under the DU uses R\&D program. Under the existing regulatory structure, these same products and devices would be exempt from such standards. Therefore, the effect of this potential future rulemaking on the existing regulatory structure applicable to products and devices that would deploy new DU uses may be substantial.

Another part of the second initiative is a proposed amendment to 10 CFR 40.51. This amendment, which was published in the Federal Register on August 28, 2002, would require prior written NRC approval for transfer of source material by an NRC licensee to any person exempt from licensing under 10 CFR 40.13(a), including a disposal facility. Since most DU-containing products and devices that deploy new DU uses would not qualify for the existing exemption in 10 CFR 40.13(a), finalization of the proposed amendment would not significantly alter the existing regulatory structure applicable to transfer of these products and devices to users by licensed manufacturers.

\section{CONCLUSIONS}

\subsection{EXISTING REGULATORY STRUCTURE}

The discussions in Section 3 indicate that under the existing regulatory structure, almost no DU-containing products and devices that deploy new DU uses being studied under the DU uses R\&D program would qualify for exemption from the licensing and other requirements of 10 CFR Part 40. It is possible that catalysts for HDS of petroleum fuels may have a DU concentration of less than $500 \mathrm{ppm}$. If this occurs, such catalysts may qualify for the exemption in 10 CFR 40.13(a). However, this appears to be an unlikely scenario. Section 3 also explains that products and devices that deploy five new DU uses may, under certain circumstances, qualify pursuant to 10 CFR 40.22 for a general license to use and transfer small quantities of source material. Nevertheless, the frequency with which the circumstances needed to qualify for the general license will arise is uncertain. The user of any DU-containing product or device that does not qualify for either an exemption or a general license must obtain a specific source material license. Accordingly, a substantial percentage of users of DU-containing products or devices that deploy new DU uses are expected to need specific source material licenses under the existing regulatory structure.

As stated in Section 3.2.2, potential users of DU-containing products and devices that are the focus of this report are expected to be non-DOE persons located in areas that are not currently 
radiologically controlled. However, as indicated above, a substantial percentage of actual users of DU-containing products and devices are expected to need specific source material licenses under the existing regulatory structure before receiving DU-containing products and devices. Therefore, potential users, who are not currently subject to radiological controls, would become subject to such controls if they become actual users. Conceivably, this could limit deployment of new DU uses because persons having no previous experience with NRC or Agreement State regulation may be hesitant to incur the costs and inconvenience of compliance, unless using a DU-containing product or device offers a substantial economic benefit over nonradioactive alternatives. A possible added deterrent to full deployment may be the need to manage discarded DU-containing products and devices as LLW.

\subsection{MODIFIED REGULATORY STRUCTURE}

The discussions in Section 4 indicate that, to the extent that they are known, anticipated and proposed modifications of the existing regulatory structure under 10 CFR Part 40 would probably not change the number of users who would need to obtain specific source material licenses before receiving DU-containing products or devices that deploy new DU uses. Furthermore, anticipated modifications to $10 \mathrm{CFR} 40.22$ would, for the first time, impose certain radiation protection standards on general licensees, which may include users of products and devices that would deploy as many as five of the new DU uses being studied under the DU uses R\&D program. Accordingly, radiation controls under the modified regulatory structure would extend to even more actual users than under the existing regulatory structure. Conceivably, this could limit deployment of new DU uses under the modified regulatory structure because persons having no previous experience with NRC or Agreement State regulation may be hesitant to incur the costs and inconvenience of compliance, unless using a DU-containing product or device offers a substantial economic benefit over nonradioactive alternatives. Also, as would be the case under the existing regulatory structure, a possible added deterrent to full deployment may be the need to manage discarded DU-containing products and devices as LLW.

\section{RECOMMENDATIONS}

As stated in Sections 5.1 and 5.2, it appears that deployment of new DU uses could be limited under the existing regulatory structure and the modified regulatory structure being contemplated by the NRC because most users of DU-containing products and devices would be required to obtain specific source material licenses. It should be noted, however, that the NRC has not previously considered whether regulatory exemptions or general licenses would be appropriate for any products or devices that may be used to deploy new DU uses into radiologically uncontrolled areas. Furthermore, neither risk nor benefit information has been developed for such products. Thus, it seems plausible that if such information were developed showing risk to be low in comparison to benefits, submission of a petition to the NRC for a regulatory change may be justified. Appendix B 
presents the requirements for preparation of such a petition, which include estimating adverse effects on health, safety, and the natural environment. Accordingly, consistent with the second aspect of the DU uses R\&D program regulatory analysis task (see Section 1), it is recommended that the DU uses R\&D program proceed with an analysis of the risk of deploying new DU-containing products and devices in certain radiologically uncontrolled areas.

\section{REFERENCES}

Atomic Energy Act of 1954, 1954, Public Law 83-703, U.S. Statutes at Large, 72 Stat. 576, Sept.

Comfort, G., 2002, personal communication from Comfort (U.S. Nuclear Regulatory Commission, Rockville, Md.) to N.L. Ranek (Argonne National Laboratory, Washington, D.C.), Sept. 17.

DOE, 2000, DUF 6 Materials Use Roadmap, Draft, Washington, D.C., Sept. 1, available at http://web.ead.anl.gov/uranium/pdf/DURoadmap.pdf. Accessed May 17, 2002.

Low-Level Radioactive Waste Policy Amendments Act of 1985, 1986, Public Law 99-240, U.S. Statutes at Large, 99 Stat. 1842, Jan. 15.

National Academy of Sciences (NAS), National Research Council, 2002, The Disposition Dilemma: Controlling the Release of Solid Materials from Nuclear Regulatory Commission-Licensed Facilities, p. 162, National Academy Press, Washington, D.C., available at http://books.nap.edu/ books/0309084172/html/162.html. Accessed Nov. 13, 2002.

NRC, 1981, 10 CFR 40.14 is Not to be Used for Issuing Exemption Licenses, HPPOS-135, PDR-9111210361, June.

NRC, 1991, 10 CFR Parts 2, 19, 20, 30, 31, 32, 34, 35, 39, 40, 50, 61 and 70 - Standards for Protection Against Radiation, final rule, 57 FR 23360, May 21.

NRC, 1992, 10 CFR Part 40 - Licensing of Source Material, advance notice of proposed rulemaking, 57 FR 48749, Oct. 28.

NRC, 1997, Staff Requirements: Risk-Informed, Performance-Based Regulation (DSI 12), COMSECY-96-061, April 15.

NRC, 1998, 10 CFR Parts 32 and 40 - Distribution of Source and Byproduct Material: Licensing and Reporting Requirements, advance notice of proposed rulemaking: withdrawal, 63 FR 68700, Dec. 14. 
NRC, 1999a, Exemption in 10 CFR Part 40 for Materials Less Than 0.05 Percent Source Material Options and Other Issues Concerning the Control of Source Material, SECY-99-259, Nov. 1, available at http://www.nrc.gov/reading-rm/doc-collections/commission/secys/1999/ secy1999-259/1999-259scy.html. Accessed Nov. 13, 2002.

NRC, 1999b, Systematic Radiological Assessment of Exemptions for Source and Byproduct Materials: Draft Report for Comment, NUREG-1717, Dec.

NRC, 1999c, 10 CFR Part 40 - State of Colorado and Organization of Agreement States; Receipt of Petition for Rulemaking, petition for rulemaking: notice of receipt, 64 FR 36615, July 7.

NRC, 2000a, Staff Requirements - SECY-99-259 - Exemption in 10 CFR Part 40 for Materials Less Than 0.05 Percent Source Material - Options and Other Issues Concerning the Control of Source Material, March 9, available at http://www.nrc.gov/reading-rm/doc-collections/commission/ srm/1999/1999-259srm.html. Accessed Nov. 13, 2002.

NRC, 2000b, Program-Specific Guidance about Possession Licenses for Manufacturing and Distribution, NUREG-1556, Vol. 12, Dec.

NRC, 2000c, 10 CFR Part 40 - Rulemaking and Jurisdictional Working Groups; Uranium and Thorium, notice of working group formation, 65 FR 52049, Aug. 28.

NRC, 2001, Systematic Radiological Assessment of Exemptions for Source and Byproduct Materials, NUREG-1717, June.

NRC, 2002a, Update of the Risk-Informed Regulation Implementation Plan, SECY-02-0131, July 12, available at http://www.nrc.gov/reading-rm/doc-collections/commission/secys/2002/ secy2002-0131/2002-0131secy.html. Accessed Nov. 13, 2002.

NRC, 2002b, Meeting Summary Part 40 Jurisdictional Working Group March 6-7, 2002, NRC Agency Document Management System (ADAMS) Accession No. ML020920593, March 6, available at http://www.nrc.gov/materials/src-materials-facilities/jurisdictional.html. Accessed Aug. 16, 2002.

NRC, 2002c, Low-Level Waste Disposal, What We Regulate, available at http://www.nrc.gov/ waste/llw-disposal.html. Accessed Sept. 16, 2002.

NRC, 2002d, 10 CFR Part 40 - Transfers of Certain Source Materials by Specific Licensees, proposed rule, 67 FR 55175, Aug. 28.

NRC, 2002e, Staff Requirements - SECY-02-0133 - Control of Solid Materials: Options and Recommendations for Proceeding, Oct. 25, available at http://www.nrc.gov/reading-rm/doccollections/commission/srm/2002/2002-0133srm.pdf. Accessed November 13, 2002. 
NRC, 2002f, Control of Solid Materials: Options and Recommendations for Proceeding, SECY-020133, July 15, available at http://www.nrc.gov/reading-rm/doc-collections/commission/secys/2002/ secy2002-0133/2002-0133scy.html. Accessed Nov. 13, 2002.

NRC, 2002g, "NRC to Develop Proposed Regulation on Control of Slightly Radioactive Solid Materials," NRC NEWS, No. 02-130, Nov. 6.

Nuclear Waste Policy Act of 1982, 1983, Public Law 97-425, as amended, U.S. Statutes at Large, 96 Stat. 2201, Jan. 7.

Resource Conservation and Recovery Act of 1976, 1976, Public Law 94-530, as amended, U.S. Statutes at Large, 90 Stat. 2795, Oct. 31.

U.S. Department of Energy: see DOE.

U.S. Nuclear Regulatory Commission: see NRC. 
APPENDIX A:

SPECIFIC LICENSE APPLICATION CONTENT AND PROCESS REQUIREMENTS 


\section{APPENDIX A: Specific License Application Content and Process Requirements}

Reference

(10 CFR)

40.31(a)

40.31(f)

40.31(b)

40.31(b)

40.31(e)

$40.31(\mathrm{~g})$

40.31(i)

$40.31(\mathrm{j})$

40.32
Requirement

Applicant must file an application on U.S. Nuclear Regulatory Commission (NRC) Form NRC 313, "Application for Material License."

If the activity being licensed is one that the NRC has determined will significantly affect the quality of the human environment, Applicant must file application and an Environmental Report at least nine months before commencing construction.

Applicant must ensure that the application is signed by an authorized person.

Applicant must respond to NRC requests for additional information.

Applicant must pay the license application fee required by Title 10, Part 170.31 of the Code of Federal Regulations (10 CFR 170.31). As of June 24, 2002, the fee for a new license was $\$ 6,000$.

If requested by the NRC, Applicant must file installation information as described in 10 CFR 75.11 on Form N-71.

Applicant must provide a proposed decommissioning funding plan to the NRC, or a certification of financial assurance for decommissioning as required by 10 CFR 40.36.

In an application to possess uranium hexafluoride in excess of $50 \mathrm{~kg}$ in a single container or 1,000 kg total, Applicant must include either:

- An evaluation showing that the maximum intake of uranium by a member of the public due to a release would not exceed $2 \mathrm{mg}$; or

- An emergency plan for responding to the radiological and chemical hazards of an accidental release.

Applicant must ensure that the application contains information sufficient for the NRC to determine the following:

- Applicant will use source material for a purpose authorized by the Atomic Energy Act;

- Applicant is qualified to use source material for the purpose requested;

- Applicant's proposed equipment, facilities, and procedures are adequate to protect health and minimize danger to life and property;

- Issuance of the license will not harm the common defense and security or the health and safety of the public; and

- Issuance of the license is the appropriate agency action alternative after taking into account the environmental, economic, technical, and other benefits against environmental costs and considering available alternatives as required by the National Environmental Policy Act (NEPA). 


\section{APPENDIX A: (Cont.)}

Reference

(10 CFR)

Requirement

40.34

If the application is for a specific license to manufacture industrial products and devices containing depleted uranium, or to initially transfer such products or devices for use under the general license granted in 10 CFR 40.25, ensure that the application contains information sufficient for the NRC to determine the following:

- The general requirements of 10 CFR 40.32 (see above) are satisfied;

- There is reasonable assurance that possession, use, or transfer of the depleted uranium in the product or device is not likely to cause any individual to receive in one year a radiation dose in excess of $10 \%$ of the annual limits allowed by 10 CFR 20.1201(a) (Occupational Dose Limits for Adults); and

- The product or device will provide unique benefits to the public because of its usefulness; or, if benefits are questionable, the product or device will combine a high degree of utility and low probability of uncontrolled disposal and dispersal of significant quantities of depleted uranium into the environment.

2.103(b) If the NRC finds that the application does not comply with all requirements, the NRC may publish a notice of proposed denial or a notice of denial of the application.

2.103(a) and 2.104(a) If the NRC finds that the application complies with all requirements and finds that a public hearing is required in the public interest, the NRC will publish a notice of hearing in the Federal Register at least 15 days before the hearing date.

2.103(a), 2.104(a), and 2.105(a)(9)

If the NRC finds that the application complies with all requirements and does not find that a public hearing is required in the public interest, the NRC will publish a notice of intent in the Federal Register to issue a permit.

2.105(d) Within 30 days of notice of intent to issue a permit, the Applicant or any person whose interest may be affected by issuance of the license may file a request for a hearing or a petition for leave to intervene.

2.105(e) If no hearing or leave to intervene is requested, the NRC may issue the permit, inform the appropriate state and local officials, and publish a notice of issuance of the license in the Federal Register.

2.106(a) After a hearing, or at any other time that the NRC issues a license, the NRC will publish a notice of issuance in the Federal Register. 
APPENDIX B:

U.S. NUCLEAR REGULATORY COMMISSION RULEMAKING PETITION CONTENT AND PROCESS REQUIREMENTS AND GUIDANCE 
APPENDIX B: U.S. Nuclear Regulatory Commission (NRC) Rulemaking Petition Content and Process Requirements and Guidance

\begin{tabular}{|c|c|c|c|}
\hline $\begin{array}{l}\text { Reference } \\
(10 \text { CFR })\end{array}$ & Requirement $^{\mathrm{a}}$ & $\begin{array}{c}\text { Reference } \\
(\text { Reg. Guide 10.12) }\end{array}$ & Guidance \\
\hline $2.802(a)$ & $\begin{array}{l}\text { Petition to issue, amend, or } \\
\text { rescind any regulation may be } \\
\text { filed by mail, by facsimile, by } \\
\text { hand delivery, or by electronic } \\
\text { submission. }\end{array}$ & None & \\
\hline $2.802(b)$ & $\begin{array}{l}\text { Prospective petitioners may } \\
\text { consult with the NRC before } \\
\text { filing a petition, but assistance } \\
\text { provided by the NRC staff is } \\
\text { limited to describing the filing } \\
\text { process, clarifying the regulations, } \\
\text { and assisting the prospective } \\
\text { petitioner with articulation of } \\
\text { issues. }\end{array}$ & None & \\
\hline $2.802(\mathrm{c})(1)$ & $\begin{array}{l}\text { Petition must specify the text of } \\
\text { any proposed regulation or } \\
\text { amendment. }\end{array}$ & 1.1 & $\begin{array}{l}\text { The suggested regulatory text } \\
\text { should be worded as directly, } \\
\text { clearly, concisely, and } \\
\text { unambiguously as possible, and } \\
\text { if possible, be in the form of an } \\
\text { amendment to existing NRC } \\
\text { regulations as codified in } \\
10 \text { CFR Chapter } 1 .\end{array}$ \\
\hline $2.802(\mathrm{c})(2)$ & $\begin{array}{l}\text { Petition must clearly and } \\
\text { concisely state the petitioner's } \\
\text { grounds for and interest in the } \\
\text { requested regulatory change. }\end{array}$ & None & \\
\hline \multirow[t]{2}{*}{$2.802(\mathrm{c})(3)$} & $\begin{array}{l}\text { Petition must include a supporting } \\
\text { statement addressing the } \\
\text { following: }\end{array}$ & 1.4 & $\begin{array}{l}\text { Petition should include a } \\
\text { regulatory analysis evaluating all } \\
\text { factors relevant to making a } \\
\text { regulatory decision and } \\
\text { providing the basis for } \\
\text { determining whether the NRC } \\
\text { staff should proceed with a } \\
\text { proposed rulemaking. }\end{array}$ \\
\hline & - The specific issues involved; & 1.4 & $\begin{array}{l}\text { The regulatory analysis should } \\
\text { contain sufficient detail to enable } \\
\text { the NRC staff to easily recognize } \\
\text { the problem within the context of } \\
\text { the existing regulatory } \\
\text { framework. }\end{array}$ \\
\hline
\end{tabular}




\section{APPENDIX B: (Cont.)}

\begin{tabular}{|c|c|c|c|}
\hline $\begin{array}{l}\text { Reference } \\
(10 \text { CFR })\end{array}$ & Requirement $^{\mathrm{a}}$ & $\begin{array}{c}\text { Reference } \\
(\text { Reg. Guide 10.12) } \\
\end{array}$ & Guidance \\
\hline & $\begin{array}{l}\text { - The petitioner's views or } \\
\text { arguments with respect to the } \\
\text { issues; }\end{array}$ & 1.4 & $\begin{array}{l}\text { The regulatory analysis should } \\
\text { contain sufficient detail to enable } \\
\text { the NRC staff to easily } \\
\text { recognize: } \\
\text { - The conclusions reached and } \\
\text { the bases for these } \\
\text { conclusions; } \\
\text { - The sources and magnitude of } \\
\text { uncertainties that might affect } \\
\text { the conclusions and the } \\
\text { proposed new regulatory } \\
\text { provisions; and } \\
\text { - The sensitivity of the } \\
\text { conclusions to changes in } \\
\text { underlying assumptions and } \\
\text { considerations. }\end{array}$ \\
\hline & - Relevant data; & 1.4 & $\begin{array}{l}\text { The regulatory analysis should } \\
\text { contain sufficient detail to enable } \\
\text { the NRC staff to easily recognize } \\
\text { the specific data and analytical } \\
\text { methods used and the logic } \\
\text { followed that led to the } \\
\text { conclusion that the proposed new } \\
\text { regulatory provisions are } \\
\text { appropriate and justified. }\end{array}$ \\
\hline & $\begin{array}{l}\text { - Other pertinent information to } \\
\text { support the proposed action. }\end{array}$ & 1.4 & $\begin{array}{l}\text { The regulatory analysis should } \\
\text { identify reasonable alternatives } \\
\text { to the proposed action and } \\
\text { provide a preliminary analysis of } \\
\text { the feasibility, values, and } \\
\text { impacts of each alternative. }\end{array}$ \\
\hline & & 1.3 & $\begin{array}{l}\text { The petition should address } \\
\text { pertinent legal requirements that } \\
\text { the NRC staff must consider for } \\
\text { rulemaking actions. Examples } \\
\text { include: }\end{array}$ \\
\hline & & & $\begin{array}{l}\text { Environmental impacts } \\
\text { pursuant to the National } \\
\text { Environmental Policy Act; }\end{array}$ \\
\hline & & & $\begin{array}{l}\text { - Information collection } \\
\text { requirements under the } \\
\text { Paperwork Reduction Act; and }\end{array}$ \\
\hline & & & $\begin{array}{l}\text { Economic Impact on Small } \\
\text { Entities under the Regulatory } \\
\text { Flexibility Act. }\end{array}$ \\
\hline
\end{tabular}




\section{APPENDIX B: (Cont.)}

\begin{tabular}{|c|c|c|c|}
\hline $\begin{array}{l}\text { Reference } \\
(10 \text { CFR })\end{array}$ & Requirement $^{\mathrm{a}}$ & $\begin{array}{c}\text { Reference } \\
\text { (Reg. Guide 10.12) }^{\mathrm{b}}\end{array}$ & Guidance \\
\hline \multirow[t]{2}{*}{$2.802(\mathrm{e})$} & $\begin{array}{l}\text { If the NRC finds the petition } \\
\text { complete: }\end{array}$ & None & \\
\hline & $\begin{array}{l}\text { - A docket number will be } \\
\text { assigned; } \\
\text { - A copy will be posted on the } \\
\text { NRC Web site; and } \\
\text { - Public comments may be } \\
\text { requested by publication of a } \\
\text { notice in the Federal Register. }\end{array}$ & & \\
\hline \multirow[t]{3}{*}{$2.802(\mathrm{f})$} & $\begin{array}{l}\text { If the NRC finds the petition } \\
\text { incomplete: }\end{array}$ & None & \\
\hline & $\begin{array}{l}\text { The petitioner will be notified; } \\
\text { and }\end{array}$ & & \\
\hline & $\begin{array}{l}\text { The petitioner will be given } \\
90 \text { days to submit additional } \\
\text { data. }\end{array}$ & & \\
\hline \multirow[t]{2}{*}{2.803} & $\begin{array}{l}\text { - If the NRC commissioners find } \\
\text { it advisable, a public hearing } \\
\text { will be held on the petition. }\end{array}$ & None & \\
\hline & $\begin{array}{l}\text { The NRC will notify the } \\
\text { petitioner of the grounds for } \\
\text { denial, if the petition is denied. }\end{array}$ & None & \\
\hline 2.804 & $\begin{array}{l}\text { If the petition is found to present } \\
\text { sufficient reason, the NRC will } \\
\text { publish a notice of proposed } \\
\text { rulemaking, including a request } \\
\text { for public comments in the } \\
\text { Federal Register. }\end{array}$ & None & \\
\hline
\end{tabular}

a Summaries are provided of the cited regulatory requirements. The regulations in Title 10, Code of Federal Regulations, Part 2, Subpart H (10 CFR Part 2, Subpart H) should be consulted to determine the exact language of each requirement.

b U.S. Nuclear Regulatory Commission, 1996, Preparation of Petition for Rulemaking under 10 CFR 2.802 and Preparation and Submission of Proposals for Regulatory Guidance Documents, Regulatory Guide 10.12, Dec. 
APPENDIX C:

\section{GLOSSARY}




\section{APPENDIX C:}

\section{GLOSSARY}

Agreement State - Section 274 of the Atomic Energy Act of 1954 (AEA 1954) (42 United States Code [U.S.C.] 2021) establishes a statutory framework under which the U.S. Nuclear Regulatory Commission (NRC) and States can agree to cooperate in the administration of regulatory programs for the protection of public health and safety in the industrial, medical, and research uses of source, byproduct, and special nuclear material in quantities not exceeding a critical mass. States with which the NRC has reached such agreements are known as "Agreement States." Each Agreement State must adopt and enforce regulations substantially equivalent to NRC regulations.

Depleted uranium - Depleted uranium is uranium that has had some of its naturally occurring 0.72 percent by weight uranium-235 content removed. Most of the U.S. Department of Energy's depleted uranium inventory contains between 0.2 to 0.4 percent by weight uranium-235, well below levels necessary to create a nuclear chain reaction.

DUF $\boldsymbol{F}_{6}$ conversion products - "DUF ${ }_{6}$ conversion" refers to the chemical transformation of depleted uranium hexafluoride $\left(\mathrm{DUF}_{6}\right)$ to another chemical form, such as depleted uranium oxide. In addition to producing depleted uranium oxide, the $\mathrm{DUF}_{6}$ conversion process may also generate other potentially usable chemicals, such as fluorine gas $\left(\mathrm{F}_{2}\right)$, hydrogen fluoride $(\mathrm{HF})$, or calcium difluoride $\left(\mathrm{CaF}_{2}\right)$. In this report, the term "DUF $\mathrm{D}_{6}$ conversion products" refers to all usable chemicals produced by the $\mathrm{DUF}_{6}$ conversion process.

General license - The NRC and Agreement States issue two types of licenses for activities related to source material: general licenses and specific licenses. General licenses are granted in the regulations and are effective without the filing of applications or the issuance of licencing documents to particular persons (Title 10, Part 40.20(a), of the Code of Federal Regulations [10 CFR 40.20(a)]), although some general licensees under 10 CFR 40.25 must register with the NRC.

Hazardous waste - Discarded material defined by the U.S. Environmental Protection Agency in 40 CFR 261.3 as hazardous waste pursuant to the Resource Conservation and Recovery Act (RCRA 1976).

Low-level radioactive waste - Radioactive material that is not high-level radioactive waste, spent nuclear fuel, or byproduct material (as defined in Section 11(e)(2) of the AEA of 1954) and that the NRC classifies as low-level radioactive waste [42 U.S.C. 2021b(9)].

Mixed waste - A waste that contains both radioactive material subject to the AEA of 1954 and hazardous waste subject to RCRA (1976). 
Radiologically controlled area - In this report, a radiologically controlled area means any area inside the boundary of a U.S. Department of Energy site or a site licensed by the NRC or an Agreement State to which access can be limited for any reason.

Source material - Uranium or thorium in any chemical or physical form, or ores containing these materials in concentrations by weight of one-twentieth of one percent $(0.05 \%)$ or more (10 CFR 40.4).

Specific license - The NRC and Agreement States issue two types of licenses for activities related to source material: general licenses and specific licenses. A person who expects to receive, possess, use, or transfer source material not covered by an exemption or a general license must apply for a specific license. The NRC or an Agreement State may issue a specific license to a named person upon completion of a licencing process that involves submission of an application by the applicant, payment of a fee by the applicant, review of the application by the responsible regulatory agency, and consideration of public comments by the responsible regulatory agency (10 CFR Part 40). 